\title{
Sexual and Reproductive Rights from Qur'anic Perspective: A Quantitative Content Analysis
}

\author{
Roksana Janghorban $^{1,2}$, Robab Latifnejad Roudsari ${ }^{3}$, Ali Taghipour ${ }^{4}$ \& Mahmoud Abbasi ${ }^{5}$ \\ 1 Student Research Committee, Department of Midwifery, School of Nursing and Midwifery, Mashhad \\ University of Medical Sciences, Mashhad, Iran \\ ${ }^{2}$ Maternal-Fetal Medicine Research Center, Shiraz University of Medical Sciences, Shiraz, Iran \\ ${ }^{3}$ Research Center for Patient Safety, Department of Midwifery, School of Nursing and Midwifery, Mashhad \\ University of Medical Sciences, Mashhad, Iran \\ ${ }^{4}$ Health Sciences Research Center, Department of Biostatistics and Epidemiology, School of Health, Mashhad \\ University of Medical Sciences, Mashhad, Iran \\ ${ }^{5}$ Medical Ethics and Law Research Center, Shahid Behshti University of Medical Sciences, Tehran, Iran \\ Correspondence: Robab Latifnejad Roudsari, Associate Professor in Reproductive Health, Research Centre for \\ Patient Safety, Department of Midwifery, School of Nursing and Midwifery, Mashhad University of Medical \\ Sciences, Ebne-Sina Street, Mashhad, Iran. Tel: 98-513-859-8016. Fax: 98-513-859-8016. E-mail: \\ LatifnejadR@mums.ac.ir
}

\author{
Received: September 28, 2014 Accepted: November 3, $2014 \quad$ Online Published: December 30, 2014 \\ doi:10.5539/ass.v11n3p182 \\ URL: http://dx.doi.org/10.5539/ass.v11n3p182
}

\begin{abstract}
The Qur'an, as the primary and main source of Islamic rules, provides a rich variety of human rights including women's rights. These rules are not static; they are dynamic and flexible in character. The flexibility of the rules in Islam is intentional, as Islam was revealed for all people and for all millennia. It is an essential aspect of Qur'anic philosophy. Consequently, its jurisprudence must be capable of responding to widely diverse needs and problems. To understand the Islamic stance on sexual and reproductive health rights, it is necessary to search the verses of the Qur'an more carefully. This study has provided an understanding of women's sexual and reproductive rights in Qur'an from a human rights perspective.

This study was conducted using quantitative content analysis of all verses of the Qur'an. After creating a coding scheme of Qur'an's verses, four categories related to the main areas of women's sexual and reproductive rights including sexual relationships, reproductive choice, prohibition of violence against women, and gender equity were determined and their presence and frequency were identified. The MAXqda software, version 2007, was used for organizing and managing the data. Descriptive analysis was used to summarize and describe data.

More than 30 surahs and 93 verses of the Qur'an had various concepts in relation to sexual and reproductive rights. In general, concepts related to the women's sexual and reproductive rights have been appeared 98 times in the Qur'an. The most frequently reported categories were related to sexual relationships (31 times) and reproductive choice (27 times) and the least reported one was prohibition of violence against women (16 times).

This study showed that the concepts related to sexual and reproductive rights have extensively appeared in the Qur'an. Based on Qur'anic perspective, women in addition to autonomy have reproductive and sexual rights in order to actualize of their human capacity.
\end{abstract}

Keywords: Qur'an, reproductive rights, sexual rights

\section{Introduction}

Sexual and reproductive rights are one of the basic human rights. The concept of Sexual and Reproductive Health and Rights (SRHR) was first declared as a human right at the International Conference in Population and Development (ICPD), in Cairo, Egypt, 1994 (United Nations Population Information Network [POPIN], 1994). The definition of reproductive health agreed upon by World Health Organization (WHO) also represented sexual health (World Health Organization [WHO], 2004). 
WHO has defined sexual health as a condition of physical, emotional, mental, and social well-being with regard to sexuality, not merely the absence of disease, dysfunction or infirmity. Sexual health requires an optimistic and respectful approach to sexuality and sexual relationships, which include the possibility of having pleasurable and safe sexual experiences, free of coercion, discrimination, and violence (WHO, 2004). To attain and maintain sexual health, the sexual rights of each and every individual must be respected, protected, and realized. WHO has also defined sexual rights as human rights that are recognized in both national laws and international human right documents, as well as many other consensus documents. They comprise the notion of an individual's right to the highest possible standard of health with respect to sexuality without bias, discrimination, and violent behavior up to and including access to sexual and reproductive health care services; to appeal for, receive and convey information with regard to sexuality; sexual education; respect for bodily integrity; choice of partner; to choose to become sexually active or not; to mutually consent to take part in the sexual act; marriage by consent; to freely choose whether or not to have children besides the right to decide the suitable time and circumstances in which to do so; and moreover, to engage in a satisfying, secure, and enjoyable sexual life (WHO, 2002).

The Holy Qur'an is a book for guidance of human beings and the primary and main source of Islamic rules (Yousuf \& Sharma, 2014). These rules are not static; they are dynamic and flexible in character. The flexibility of the rules in Islam is intentional, as Islam was revealed for all people and for all millennia. It is an essential aspect of Qur'anic philosophy. As a consequence the rules must be capable of meeting diverse needs and challenges (Mwenegoha, 2008). One of the most important needs is concerned with safeguarding the rights of human beings. The Qur'an affirms a rich variety of the fundamental rights that all persons possess (Hashemi \& Qureshi, 2014).

Most of the human rights studies from Qur'anic perspectives have focused on right to life, right to respect, right to justice, right to freedom, right to privacy and right to protection from defamation, sarcasm, offensive nicknames, and backbiting (Yousuf \& Sharma, 2014; Hassan, 2009). It seems that few studies have been conducted on women's rights especially their sexual and reproductive rights in Qur'an (Omari Mwenegoha, 2008; Hosseini \& Esmaeilzadeh, 2013; Ahmad Khan, 2009; Janghorban, Latifnejad Roudsari, Taghipour \& Abbasi, 2014). To understand the fullness of the Islamic stance on sexual and reproductive health rights, it is necessary to consider the verses of the Qur'an more carefully. This study has provided an understanding of women's sexual and reproductive rights in Qur'an from a human rights perspective.

\section{Methods}

This exegetic study was conducted using quantitative content analysis of all verses of the Qur'an in which the presence and frequencies of categories were identified. Content analysis is a rapidly growing technique in the domain of quantitative research. Neuendorf (2002) stated that the method "may be briefly defined as the systematic, objective, quantitative analysis of message characteristics".

Three kinds of units are employed in this content analysis: analyzing unit, context unit, and recording unit (Krippendorff, 1980). The analyzing unit was all 114 surahs of the Holy Qur'an. The context unit was each surah and the recording unit was the idea(s) related to sexual and reproductive rights in each verse. Thus a verse could be coded in multiple separate recording units, with each idea belonging to only one category. The exegetic approach of the study was the thematic approach. In this approach, the authors were focused on seeking the concept of sexual and reproductive rights in Qur'an. At first, the various aspects of the concept were raised according to the main identified categories then the Qur'anic replies to them were sought. Coding of Qur'an verses was carried out in four categories related to the main areas of women's sexual and reproductive rights including sexual relationships, reproductive choice, prohibition of violence against women, and gender equity. For this study two trained coders, including the primary researcher examined the surahs, the verses and phrases. Each coder independently coded the recording units then inter-coder reliability was measured for checking the amount of agreement or consensus between two coders. It was calculated by dividing the number of units placed in the same category by the number of units coded. The agreement between two coders was 87 percent. The MAXqda software, version 2007, was used for organizing and managing the data. Descriptive analysis was used to summarize and describe data.

\section{Results}

More than $30(26.3 \%)$ surahs and $93(1.5 \%)$ verses of the Qur'an had various concepts about sexual and reproductive rights (Table 1). These chapters consist of 19 (63.3\%) "Meccan surahs" and 11(36.7\%) "Medinan surahs". Out of 30 chapters, Al-Baqara addressed the most sexual and reproductive rights-related issues in the Qur'an. 
In general, concepts related to women's sexual and reproductive rights have been appeared 98 times in the Qur'an (Table 2). The most frequently reported categories were related to sexual relationships (31 times) and reproductive choice (27 times) and the least one was prohibition of violence against women (16 times). Through coding process, subcategories of identified categories were also sought and their frequency was identified. The category of sexual relationships subsumed four subcategories of homosexual acts prohibition, conditions of heterosexual relationship, prohibition of incest, and mutual responsibility. Category of reproductive choice consisted of two subcategories of right to newborn life and prenatal stages. Prohibition of violence against women was divided to marriage and divorce subcategories. The category of gender equity had two subcategories including human identity and gender identity. Out of all subcategories, the subcategory of human identity had the most frequency. In Table 2, details of frequency of the categories and subcategories are shown.

Table1. Frequency distribution of surahs and verses of the Qur'an related to sexual and reproductive rights

\begin{tabular}{cccccc}
\hline Surahs & Verses & \multirow{2}{*}{ Surahs } & Verses & \multirow{2}{*}{ Surahs } & Verses \\
& $\mathrm{N}(\%)$ & & $\mathrm{N}(\%)$ & A $(\%)$ \\
\hline Al-Baqara & $17(18.4)$ & Al-Mu'minun & $3(3.2)$ & Az-Zukhruf & $1(1.1)$ \\
'Ale Imran & $1(1.1)$ & An-Nour & $10(10.8)$ & Al-'Ahqaf & $1(1.1)$ \\
An-Nisa' & $14(15.1)$ & An-Naml & $2(2.1)$ & An-Najm & $3(3.2)$ \\
Al-Ma'idah & $2(2.1)$ & Ash-Shu'ara & $1(1.1)$ & Al-Hadid & $3(3.2)$ \\
Al-An'am & $2(2.1)$ & Al-'Ankabut & $2(2.1)$ & Al-Mumtahanah & $1(1.1)$ \\
Al-A'raf & $3(3.2)$ & Ar-Rum & $1(1.1)$ & At-Talaq & $4(4.3)$ \\
At-Tawbah & $2(2.1)$ & Luqman & $1(1.1)$ & Nouh & $1(1.1)$ \\
An-Nahl & $3(3.2)$ & Al-'Ahzab & $5(5.4)$ & Al-Muddathir & $1(1.1)$ \\
Al-' Isra' & $2(2.1)$ & Ghafir & $1(1.1)$ & At-Takwir & $2(2.1)$ \\
Al-Haj & $1(1.1)$ & Ash-Shuraa & $2(2.1)$ & Al-Buruj & $1(1.1)$ \\
\hline
\end{tabular}

Table 2. Frequency distribution of categories and subcategories related to sexual and reproductive rights

\begin{tabular}{lll}
\hline Categories & Subcategories & N (\%) \\
\hline Sexual relationships & Homosexual acts prohibition & $7(7.1)$ \\
& Conditions of heterosexual relationship & $9(9.2)$ \\
& Prohibition of incest & $2(2.0)$ \\
& Mutual responsibility & $13(13.3)$ \\
Reproductive choice & Right to newborn life & $9(9.2)$ \\
& Prenatal stages & $13(13.3)$ \\
& Right to choose family planning method & $5(5.1)$ \\
Prohibition of violence against women & Marriage & $2(2.0)$ \\
& Divorce & $14(14.3)$ \\
Gender equity & Human identity & $21(21.4)$ \\
& Gender identity & $3(3.1)$ \\
\hline
\end{tabular}

\section{Discussion}

The extension of the concepts related to sexual and reproductive rights is visible throughout the Qur'an including both Meccan and Medinan surahs. The Meccan surahs are comprised of the chronologically earlier chapters of the Qur'an that were made known some time before the prophet Muhammed and his followers migrated from Mecca to Medina. The Medinan surahs are the revelations that followed their move to the city of Medinah.

The Qur'an affirms mutual responsibility for couples in their conjugal life. In the Qur'an this relationship is clarified as having two major qualities: love (passion, friendship, companionship), and compassion (understanding, reconciliation, tolerance, forgiveness) with the overall intention of serenity in the marriage (Omran, 1992). It is clear that their mutual responsibility, especially in the sexual relationship, could fulfill peace and satisfaction in their marital life. The Qur'an explains what this means:

"... and one of Allah's signs is, that He has created wives for you from yourselves, that you may live in harmony together, and has ordained Love and Mercy between you." (30:21 Surah Ar-Rum)

The Qur'an protects the family from breakdown by forbidding all types of sexual relations outside marriage including incest, adultery, and homosexual relationships (Qur'an 4:21,22 Surah An-Nisa', 7:80,81 Surah 
Al-A'raf, and 24: 2-9 Surah An-Nour). Marital commitment could guarantee trust and stability between couples. A relationship with strong commitment provides a greater sense of security and sexual satisfaction (Christopher \& Spercher, 2000). The Qur'an pays special attention to marital commitment and reprimands adultery in some verses such as:

"And do not approach committing adultery, it is an indecent and shameful act which leads to an evil way." (17:32 Surah Al-' Isra')

Additionally, the Qur'an provides women and men the right to sexual health by prohibiting anything believed to be harmful. One of the issues is prohibition of having sex within menstrual cycle. Although the biological sex throughout the menstrual period is possible, in most cultures it is a risky act (Barnard A, Spencer, 2009). Medical knowledge confirms the Qur'anic perspective due to the increased risk of sexually transmitted infections during the menstruation (Koray \& Sevgi, 1996). Using condom in a sexual relationship throughout menstruation period could decrease the risk of sexually transmitted infections but could not completely prevent from the transmission of the infections. The risk does not limit to women, as having sexual contact during menstruation could encounter men to blood due to some sexual activities except vaginal intercourse and the issue could transmit these infections. Kalichman and Simbayi (2004) in their study confirmed this issue. The Holy Qur'an says:

"They ask you concerning women's course. Say: It is a discomfort, so keep away from women in their courses, and do not approach them until they have purified themselves. When they are clean, approach them as Allah has commanded you. Truly, God loves those who constantly seek Him and loves those who keep themselves pure and clean." (2:222Surah Al-Baqara)

On the other hand, the Holy Qur'an has so many verses that point out the different aspects of reproductive rights and reproductive choices. First, it supports the right to life and prohibits Muslims from infanticide which was a pre-Islamic practice motivated by financial problems and gender consideration (Qur'an 17:31 Surah Al-Isra and 6:151 Surah Al-An'am).

Although the Qur'an encourages life, it does not oppose the right to choose contraception (Omari Mwenegoha, 2008). Indeed, the Qur'anic verses refer to prenatal stages (Qur'an 22:5 Surah Al-Haj, 23:13,14 Surah Al-Mu'minun, 7:189 Surah Al-A'raf, 29:29 Surah Al-'Ankabut, and 53:46 Surah An-Najm), right to life, and contraception. However, the Qur'an indirectly addresses population control issues. Breastfeeding as a natural contraception method has been introduced in some verses (Qur'an 2:233 Surah Al-Baqara, 31:14 Surah Luqman, and 46:15 Surah Al-'Ahqaf). The Holy Qur'an says:

"The mothers shall provide breastfeeding to their children for two whole years, (that is) for the mother who desires to. However, the cost of the mother's food and clothing must be borne by the father of the child on a reasonable basis... If both parents choose not to continue and mutually decide on weaning, after due consultation, there is no sin on them. If a foster-mother is chosen for your children there is no blame on you, provided you pay (her) what you agreed, on equitable terms. But fear Allah and know that He sees what you do." (2:233, Surah Al-Baqara)

Also, the Qur'an supports the concept of reproductive rights and autonomy. Some verses show that each person has responsibility of his or her actions (Qur'an 74:38 Surah Al-Muddathir, and 52: 21 Surah At-Tur). Although the Qur'an describes God as the sustainer of all creations, it does not make individuals free from accepting responsibility for their survival and well-being. It notes that human beings have the right to freedom of choice. All these ideas support individual's responsibility where reproductive choice is considered.

Although the Universal Declaration of Human Rights in 1948 was a landmark in recognition of the right to marry free from discrimination, coercion, and violence and full consent (United Nations, 1948), this issue was considered many centuries ago in the Qur'an. The issue of marriageable age is a very important factor which provides an opportunity for a woman to exercise her reproductive rights (Svanemyr, Chandra-Mouli, Sigurdson Christiansen \& Mbizvo, 2012). For a person to fully and freely consent to marriage, she/he should be at of legal age; that is, the age by which an individual acquires the physical, intellectual, psychological and emotional state to determine the importance and magnitude of the concept of marriage. The Holy Qur'an explains what the age of majority means:

"And try orphans (with regard to their intellect) until they reach marriageable age; at this point if sound judgment is observed in them, return their possessions to them. Do not waste them and hastily use them, fearing that they should grow up. If one (amongst guardians) is rich, let him take no wages, but if he is poor, allow him 
to take what is just and reasonable (according to his work). And when properties are returned to them, there should be some witnesses present; and Allah is sufficient in taking account." (4:6 Surah An-Nisa')

Additionally, the Glorious Qur'an prohibits violence against women not only in marriage but also in divorce (Qur'an 2:228,229,236 Surah Al-Baqara, 33:49 Surah Al-'Ahzab, and 65: 1,2,4,6 Surah At-Talaq). For example, in Surah Al-Baqara, it implies that when you have divorced your wife, you must respectfully separate from her and you should never intend violating her rights (Qur'an 2:231 Surah Al-Baqara).

Gender equality is recognized as a cornerstone of development and a key to achieving the Millennium Development Goals (United Nations Population Fund [UNFPA], 2014). According to the Qur'an, women and men are equal in human identity and are created from a single soul (Qur'an 4:1 Surah An-Nisa', 7:189 Surah Al-A'raf). Women are entitled to equal opportunities with men in order to fulfill their human potentials. The Qur'an clarifies in numerous verses that the reward in life after death and closeness to God is not dependent upon sex, but upon faith and deeds, regardless of whether they are of a woman or a man (Qur'an 3:195 Surah 'Ale Imran, 4:32, 124 Surah An-Nisa', 9:72 Surah At-Tawbah, 16:97 Surah An-Nahl, 33:35,73 Surah Al-'Ahzab, and 40:40 Surah Ghafir).

On the other hand, the Holy Qur'an affirms the difference in gender identity. (Qur'an 46:15 Surah Al-'Ahqaf, 4:7,11,12 Surah An-Nisa'). It prohibits gender discrimination and puts emphasis on equity. Equity is different from being exactly the same because natural differences between women and men rule out the possibility of infinite equality (Aghajani, 2010; Roudgar, 2010). The Qur'an is not against the equality of men and women in human identity, but it does not agree with the identicalness of their rights according to gender identity.

\section{Conclusion}

The concept of sexual and reproductive rights and autonomy was extensively recognized by the Qur'an long before regional and international human rights declarations and conventions addressed to it.

\section{Acknowledgment}

This article has been extracted from a PhD thesis in Reproductive Health in relation to Iranian women's sexual and reproductive health rights and was funded by the Vice Chancellor for Research, Mashhad University of Medical Sciences, Mashhad, Iran (grant number: 910141). Authors acknowledge the financial support of this university.

\section{References}

Aghajani, N. A. (2010). Dilemma of feminism with gender equality. Women's Strategic Studies, 12(46), 7-48.

Ahmad Khan, A. (2009). What the Qur'an says about women's rights. Retrieved from http://www.commongroundnews.org/article.php?id=25242\&lan=en\&sp=0

Barnard, A., \& Spencer, J. (2009). The Routledge encyclopedia of social and cultural anthropology (2nd ed.). London, England: Routledge.

Christopher, H., \& Spercher, A. (2000). Sexuality in marriage, dating, and other relationship: A decade review. Journal of Marriage and Family, 62, 999-1017. http://dx.doi.org/10.1111/j.1741-3737.2000.00999.x

Hashemi, N., \& Qureshi, E. (2014). Human rights. Retrieved from http://www.oxfordislamicstudies.com/article/ opr/t236/e0325

Hassan, R. (2009). Human rights in the Quran (Part 2). Retrieved from http://www.onislam.net/english/ reading-islam/understanding-islam/ethics-and-values/human-rights/423508.html

Hosseini, Z., \& Esmaeilzadeh, S. (2013). Having sex during the menstruation from the perspective of quran and medicine. Journal of Zanjan University of Medical Sciences and Health Services, 22(90), 23-32.

Janghorban, R., Latifnejad Roudsari, R., Taghipour, A., \& Abbasi, M. (2014). A review of the concept and structure of sexual and reproductive rights in international human rights documents. Iranian Journal of Obstetrics, Gynecology and Infertility, 17(100), 16-26.

Kalichman S. C., \& Simbayi, L. C. (2004). Sexual exposure to blood and increased risks for heterosexual HIV Transmission in Cape Town, South Africa. African Journal of Reproductive Health, 8(2), 55-58.

Koray, T., \& Sevgi, A. (1996). Sexual intercourse during menstruation and self-reported sexually transmitted disease history among women. Journal of the American Sexually Transmitted Disease Association, 23(5), 395-401.

Krippendorff, K. (1980). Content analysis: An introduction to its methodology. London: Sage. 
Neuendorf, K.A. (2002). The content analysis guidebook. Thousand Oaks, CA: Sage.

Omari Mwenegoha, H. (2008). Women's reproductive rights and autonomy under Islam as they intersect with human rights entitlements and customary norms and practices in Tanzania-Lushoto as a case study (Master's thesis, University of Zimbabwe, Harare, Zimbabwe). Retrieved from http://www.searcwl.ac.zw/ index.php?option $=$ com_docman\&task $=$ doc_download\&gid $=104 \&$ Itemid $=96$

Omran, A. R.(1992). Family planning in the legacy of Islam. London: Routledge.

Roudgar, M. J. (2010). Gender equality according to Allameh Tabatabaei and Martyr Muttahari. Women's Strategic Studies, 12(46), 49-80.

Svanemyr, J., Chandra-Mouli, V., Sigurdson Christiansen, C., \& Mbizvo, M. (2012). Preventing child marriages: first international day of the girl child "my life, my right, end child marriage". Reproductive Health, 9(31), 1-3. http://dx.doi.org/10.1186/1742-4755-9-31

United Nations (UN). (1948). The Universal Declaration of Human Rights. Retrieved from http://www.un.org/en/documents/udhr/index.shtml

United Nations Population Fund (UNFPA). (2014). Gender equality: A cornerstone of development. Retrieved from http://www.unfpa.org/gender/

United Nations Population Information Network. (1994). Report of the International Conference on Population and Development (Paragraph 7.2). Retrieved from http://www.un.org/popin/icpd/conference/offeng/ poa.html

World Health Organization (WHO). (2002). Gender and reproductive rights glossary. Retrieved from http://www.who.int/reproductive-health/gender/glossary.html

World Health Organization (WHO). (2004). Sexual health-a new focus for WHO. Retrieved from http://www.who.int/hrp/publications/progress67.pdf

Yousuf, I., \& Sharma, B. (2014). A study on human rights in Islam. Golden Research Thoughts Journal, 3(9), $1-11$.

\section{Copyrights}

Copyright for this article is retained by the author(s), with first publication rights granted to the journal.

This is an open-access article distributed under the terms and conditions of the Creative Commons Attribution license (http://creativecommons.org/licenses/by/3.0/). 